\title{
РІВНІ ГОТОВНОСТІ МАЙБУТНІХ ФАХІВЦІВ ГОТЕЛЬНО-РЕСТОРАННОЇ СПРАВИ ДО ПРОФЕСІЙНОЇ ДІЯЛЬНОСТІ
}

У статті проаналізовано рівні готовності майбутніх фахівців готельно-ресторанної справи до професійної діяльності. Акцентовано на критеріях готовності майбутніх фахівців готельно-ресторанної справи до професійної діяльності: иіннісно-особистісному, гносеологічносистемному, технологічно-діяльнісному, здоров'язбережувальному. У контексті дослідження сформульовано термін «рівень» як ступінь освіти, культури й підготовленості до професійної діяльності майбутніх фахівців готельно-ресторанної справи. Виділено такі рівні готовності означених фахівиів: високий (творчий), достатній (конструктивно-варіативний), середній (репродуктивний), низький (рецептивно-продуктивний). Високий рівень властивий здобувачам освіти з глибокою потребою в постійному виявленні особливих творчих здібностей, вольової саморегуляції, самостійного здобування знань, особистісного самовдосконалення; з sрунтовними знаннями про предметну область і специифіку фахової діяльності, організацію сервісно-виробничого процесу та використанням набутих знань для прийняття рішень у нестандартних ситуаціях тощь. Достатній рівень характерний здобувачам освіти зі значно вираженою вольовою саморегуляцієюю та здібностяли до діяльності у сфері «людина - людина»; вільним володінням вивченим обсягом матеріалу, умінням застосовувати його на практиці; достатніми знаннями про предметну область і специффіку фахової діяльності, організацію сервісно-виробничого процесу тощо. Середній рівень простежуеться у здобувачів освіти, які відзначаються нестійкою вольовою саморегуляиією та здібностями до діяльності у сфері «^юдина - людина»; відсутністю стійких цільвових установок щодо особистісного зростання, схильністю до зміни власних переконань та принципів тощо. Низький рівень притаманний здобувачам освіти з відсутністю або низьким проявом вольової саморегуляції та здібностей до діяльності у сфері «людина - людина»; фрагментарним володінням навчальним матеріалом; фрагментарними знаннями про предметну область $і$ спеццифіку фахової діяльності, організацію сервісно-виробничого процесу тощо. Визначено характеристики рівнів сформованості готовності майбутніх фахівців готельно-ресторанної справи до професійної діяльності в розрізі означених критеріїв.

Ключові слова: майбутні фахівці, готельно-ресторанна справа, готовність, критерії, piвні.

Постановка проблеми. Розвиток соціуму означується динамічними змінами у всіх сферах економічної діяльності, зокрема й у готельно-ресторанному бізнесі. Виняткової ролі набуває питання формування професійної компетентності майбутніх фахівців, що своєю чергою спонукає і до змін у вищій професійній освіті. Перед закладами освіти постає завдання підготовки фахівця, відповідного запитам сучасного цифрового суспільства. Тож інтенсивність та якість освітнього процесу разом із активізацією навчально-пізнавальної діяльності здобувачів освіти потребують визначення рівнів готовності майбутніх фахівців до професійної діяльності.

Аналіз досліджень. Низка українських науковців здійснила грунтовні дослідження щодо професійної підготовки здобувачів освіти шляхом визначення критеріїв, показників та рівнів готовності майбутніх фахівців до професійної діяльності. Так, теоретичні і методичні засади професійної підготовки майбутніх фахівців з туризмознавства у вищих навчальних закладах вивчала Д. Безкоровайна [2], формування професійної компетентності майбутніх

“(C) Бурак В. Г.

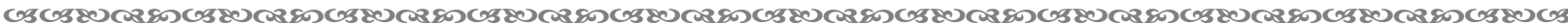
122 
менеджерів туризму засобами інформаційно-комунікаційних технологій Г. Лоїк [9]. Структуру, критерії та рівні готовності майбутніх фахівців із туризмознавства до професійної діяльності у сфері соціального туризму досліджувала Д. Аюта [10], підготовку майбутніх магістрів 3 туризмознавства до проєктної професійної діяльності А. Тимейчук [13]. Питання формування професійної культури майбутніх фахівців сфери ресторанного господарства у вищому навчальному закладі аналізував Ю. Безрученков [3], професійну підготовку майбутніх фахівців з готельно-курортної справи в умовах ступеневої освіти розгдядав А. Віндюк [6]. Створенню й обгрунтуванню моделі формування готовності до професійної діяльності майбутніх фахівців 3 готельної і ресторанної справи в результаті професійної підготовки присвячено працю К. Піцул [11], рівневій характеристиці готовності фахівців готельно-ресторанної справи до інноваційної професійної діяльності - $\lambda$. Потапкіної [12]. Модель підготовки майбутніх фахівців сфери обслуговування висвітлено А. Гарагою [7]. Вивченню критеріїв, показників та рівнів сформованості професійної компетентності майбутніх фахівців сфери послуг, зокрема в умовах освітньо-виробничого кластера, присвячено працю $А$. Короткової [8].

Мета статті полягае у визначенні рівнів готовності майбутніх фахівців готельноресторанної справи до професійної діяльності.

Виклад основного матеріалу. Оскільки готельно-ресторанна справа тісно пов'язана з туристичною галуззю, доцільним уважаємо в межах дослідження аналізувати спільний досвід підготовки майбутніх фахівців сфери обслуговування, зважаючи на його міждисциплінарний характер. Здійснений нами в попередніх дослідженнях аналіз уможливив власне визначення терміна «готовність майбутнього фахівцяя готельноресторанної справи до фахової діяльності», що аналізується нами як результат навчання в закладах фахової передвищої та вищої освіти різних форм власності, вододіння замовниками освітніх послуг професійно орієнтованими знаннями, уміннями, навичками і компетентностями, які встановлюють його відповідність вимогам до діяльності з надання різноманітних послуг клієнтам готельно-ресторанних підприемств; грунтується на усвідомлених здібностях до обраної професії, рефлексії, передбачає здатність до наукового дослідження та інноваційної діяльності, неперервний саморозвиток і самоосвіту впродовж життя [5, с. 128].

Для встановлення відповідності готовності майбутніх фахівців готельно-ресторанної справи до професійної діяльності вимогам щодо сформованих компетентностей та нормативному змісту підготовки здобувачів вищої освіти, сформульованому в термінах результатів навчання, необхідно виокремити критерії, показники та рівні. У попередніх дослідженнях нами визначено критерії готовності майбутніх фахівців готельно-ресторанної справи до професійної діяльності: ціннісно-особистісний, гносеологічно-систелний, технологічно-діяльнісний, здоров'язбережувальний. Установлено, що ціннісно-особистісний критерій характеризуе систему індивідуальних моральних, культурних, наукових цінностей, вольової саморегуляції, мотивації, придатності та здібностей до діяльності у сфері обслуговування, усвідомленість вибору роду діяльності й бажання вдосконалювати свою фахову підготовку через усвідомлення змісту. З'ясовано, що гносеологічно-системний критерій акумулюе мождивості пізнання здобувачем освіти дійсності й себе, визначення ефективних шияхів досягнення системи достовірного знання через забезпечення його повноти, глибини, гнучкості, оперативності, системності, конкретності, узагальненості. Доведено, що технологічно-діяльнісний критерій визначає практичну направленість здобувачів освіти на майбутню професійну діяльність через уміння планувати свої дії, створювати умови успішного виконання поставлених завдань; готовність 3 організації сервісно-виробничого процесу відповідно до вимог і потреб споживачів, забезпечення його ефективності. Умотивовано, що здоров'язбережувальний критерій виражає прояв наявних знань студентів щодо ведення та дотримання здорового способу життя; сформованих умінь та навичок використовувати засвоєні знання у власній здоров'язбережувальній діяльності; 
дотримання правил безпеки життєдіяльності й безпеки перебування клієнтів та співробітників у закладах сфери обслуговування.

Продовжимо дослідження з визначення рівнів готовності майбутніх фахівців готельноресторанної справи до професійної діяльності. Охарактеризуємо дефініцію означеного терміна. Так, Тлумачний словник української мови значення слова «рівень» ототожнює зі ступенем, котрий характеризуе якість, висоту, величину розвитку чогось [14, с. 230]. Академічний тлумачний словник, окрім розуміння означеного слова як ступеня якості, величини, досягнутих у чому-небудь, додає ще й значення «ступінь чиєїсь освіти, культури, підготовки» [1]. У контексті розвідки актуальним є означення терміна «рівень» як ступінь освіти, культури й підготовленості до професійної діяльності майбутніх фахівців готельноресторанної справи. Тож виділяемо такі рівні готовності означених фахівців: високий (творчий), достатній (конструктивно-варіативний), середній (репродуктивний), низький (рецептивно-продуктивний).

Високий (творчий) рівень готовності майбутніх фахівців готельно-ресторанної справи до професійної діяльності властивий здобувачам освіти, які мають: гдибоку потребу в постійному виявленні особливих творчих здібностей, вольової саморегудяції, самостійного здобування знань, особистісному самовдосконаленні; грунтовні знання про предметну область і специфіку фахової діяльності, організацію сервісно-виробничого процесу та використання набутих знання для прийняття рішень у нестандартних ситуаціях; уміння перекондиво аргументувати прийняті рішення, самостійно розкривати власні обдарування інахили; глибоке розуміння значення здоров'я як загальнолюдської цінності, стійкі пізнавальні інтереси у сфері здорового способу життя та здоров'язбереження; розвиненістю мотивації особистісного самовдосконалення та сформованістю життєвої спрямованості на активний саморозвиток та самореалізацію.

Достатній (конструктивно-варіативний) рівень готовності майбутніх фахівців готельно-ресторанної справи до професійної діяльності характерний здобувачам освіти зі значно вираженою вольовою саморегуляцією та здібностями до діяльності у сфері «людина - людина»; вільним володінням вивченим обсягом матеріалу, умінням застосовувати його на практиці; достатніми знаннями про предметну область і специфіку фахової діяльності, організацію сервісно-виробничого процесу; усвідомленим розумінням значення здоров'я як загальнолюдської цінності, стійкими пізнавальними інтересами у сфері здорового способу життя та здоров'язбереження.

Середній (репродуктивний) рівень готовності майбутніх фахівців готельноресторанної справи до професійної діяльності простежується у здобувачів освіти, які відзначаються нестійкою вольовою саморегуляцією та здібностями до діядьності у сфері «людина - людина»; відсутністю стійких цільових установок щодо особистісного зростання, схильністю до зміни власних переконань та принципів, достатніми вміннями відтворювати значну кількість матеріалу на репродуктивному рівні, виявляти розуміння основних положень; частковими знаннями про предметну область і специфіку фахової діяльності, організацію сервісно-виробничого процесу; наявною здатністю до формування та реалізації результативних зовнішніх та внутрішніх контактів, навичок взаємодії за певних обставин; достатнім розумінням значення здоров'я як загальнодюдської цінності, наявними пізнавальними інтересами у сфері здорового способу життя та здоров' язбереження.

Низъкий (рецептивно-продуктивний) рівень готовності майбутніх фахівців готельноресторанної справи до професійної діяльності притаманний здобувачам освіти з відсутністю або низьким проявом вольової саморегуляції та здібностей до діяльності у сфері «людина людина»; фрагментарним володінням навчальним матеріалом; елементарним розпізнаванням та відтворенням окремих фрагментів, фактів, елементів, об'єктів навчального матеріалу; фрагментарними знаннями про предметну область і специфіку фахової діядьності, організацію сервісно-виробничого процесу; відсутністю або низьким проявом здатності до формування та реалізації зовнішніх та внутрішніх контактів, навичок взаємодііі; відсутністю або низьким проявом здатності до розроблення нових послуг (продукціі)

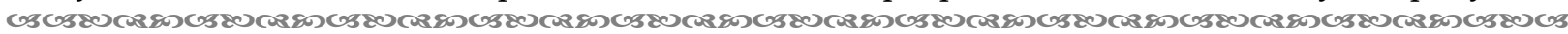


та використання інноваційних технологій; фрагментарним розумінням значення здоров'я як загальнодюдської цінності, відсутністю або низьким проявом пізнавальних інтересів у сфері здорового способу життя та здоров' язбереження.

Визначені нами рівні готовності майбутніх фахівців готельно-ресторанної справи до професійної діяльності в розрізі вищеозначених критеріїв подано в табл. 2.

Рівні сформованості готовності майбутніх фахівців готельно-ресторанної справи до професійної діяльності

\begin{tabular}{|c|c|c|c|}
\hline \multicolumn{4}{|c|}{ Ціннісно-особистісний критерій } \\
\hline високий (творчий) & $\begin{array}{c}\text { достатній } \\
\text { (конструктивно- } \\
\text { варіативний) } \\
\end{array}$ & $\begin{array}{c}\text { середній } \\
\text { (репродуктивний) }\end{array}$ & $\begin{array}{c}\text { низький } \\
\text { (рецептивно- } \\
\text { продуктивний) } \\
\end{array}$ \\
\hline 1 & 2 & 3 & 4 \\
\hline $\begin{array}{l}- \text { постійне } \\
\text { виявлення особливої } \\
\text { вольової } \\
\text { саморегуляції, } \\
\text { здібностей до } \\
\text { діяльності у сфері } \\
\text { «дюдина - дюдина»; } \\
\text { - постійні уміння } \\
\text { надавати якісні } \\
\text { послуги та добротно } \\
\text { виконувати обов'язки; } \\
\text { - постійні уміння } \\
\text { налагодити } \\
\text { співробітництво з } \\
\text { персоналом та } \\
\text { клієнтами щодо } \\
\text { прогнозування та } \\
\text { задоволення запитів; } \\
\text { - постійні навички } \\
\text { цінувати та поважати } \\
\text { різноманітність та } \\
\text { мультикультурність; } \\
\text { - постійні уміння } \\
\text { самостійно } \\
\text { розкривати власні } \\
\text { обдарування і нахили }\end{array}$ & $\begin{array}{l}\text { - } \text { наявність вольової } \\
\text { саморегуляції та } \\
\text { здібностей до діяльності } \\
\text { у сфері «людина - } \\
\text { дюдина»; } \\
\text { - наявність уміння } \\
\text { надавати якісні послуги } \\
\text { та виконувати } \\
\text { обов' язки; } \\
\text { - наявність уміння } \\
\text { налагодити } \\
\text { співробітництво з } \\
\text { персоналом та } \\
\text { споживачами щодо } \\
\text { прогнозування та } \\
\text { задоволення запитів; } \\
\text { - наявність навички } \\
\text { цінувати та поважати } \\
\text { різноманітність та } \\
\text { мультикультурність; } \\
\text { - наявність уміння } \\
\text { самостійно розкривати } \\
\text { власні обдарування і } \\
\text { нахили }\end{array}$ & $\begin{array}{l}\text { - наявність вольової } \\
\text { саморегуляції та } \\
\text { здібностей до } \\
\text { діяльності у сфері } \\
\text { «дюдина - дюдина» } \\
\text { дише за певних } \\
\text { обставин; } \\
\text { - наявність уміння } \\
\text { надавати якісні } \\
\text { послуги та виконувати } \\
\text { обов'язки за певних } \\
\text { обставин; } \\
\text { - наявність уміння } \\
\text { налагодити } \\
\text { співробітництво з } \\
\text { персоналом за певних } \\
\text { обставин; } \\
\text { - наявність навички } \\
\text { цінувати та поважати } \\
\text { різноманітність та } \\
\text { мультикультурність за } \\
\text { певних обставин; } \\
\text { - наявність уміння } \\
\text { самостійно } \\
\text { розкривати власні } \\
\text { обдарування і нахили } \\
\text { за певних обставин }\end{array}$ & $\begin{array}{l}\text { - відсутність або } \\
\text { низький прояв } \\
\text { вольової саморегуляції } \\
\text { та здібностей до } \\
\text { діяльності у сфері } \\
\text { «дюдина - дюдина»; } \\
\text { - відсутність або } \\
\text { низький прояв уміння } \\
\text { надавати якісні } \\
\text { послуги та виконувати } \\
\text { обов'язки; } \\
\text { - відсутність або } \\
\text { низький прояв уміння } \\
\text { налагодити } \\
\text { співробітництво з } \\
\text { персоналом та } \\
\text { споживачами; } \\
\text { - відсутність або } \\
\text { низький прояв } \\
\text { навички цінувати та } \\
\text { поважати } \\
\text { різноманітність та } \\
\text { мультикультурність; } \\
\text { - відсутність або } \\
\text { низький прояв уміння } \\
\text { розкривати власні } \\
\text { обдарування і нахили }\end{array}$ \\
\hline \multicolumn{4}{|c|}{ Гностично-системний критерій } \\
\hline висок & $\begin{array}{c}\text { достатній } \\
\text { (конструктивно- } \\
\text { варіативний) } \\
\end{array}$ & $\begin{array}{c}\text { середній } \\
\text { (репродуктивний) }\end{array}$ & $\begin{array}{c}\text { низький } \\
\text { (рецептивно- } \\
\text { продуктивний) }\end{array}$ \\
\hline $\begin{array}{l}\text { - постійне } \\
\text { виявлення особливих } \\
\text { творчих здібностей; } \\
\text { - майстерні уміння } \\
\text { самостійно здобувати } \\
\text { знання, знаходити та } \\
\text { опрацьовувати } \\
\text { необхідну інформацію } \\
\text { через навички } \\
\text { використання } \\
\text { цифрових технологій; }\end{array}$ & $\begin{array}{l}\text { - вільне володіння } \\
\text { вивченим обсягом ма- } \\
\text { теріалу, уміння засто- } \\
\text { совувати його на } \\
\text { практиці; } \\
\text { - досконалі уміння } \\
\text { зіставляти, узагальню- } \\
\text { вати, систематизувати } \\
\text { інформацію, самостій- } \\
\text { но виправляти допуще- } \\
\text { ні помилки, кількість } \\
\text { яких незначна; }\end{array}$ & $\begin{array}{l}\text { - достатні уміння } \\
\text { відтворювати значну } \\
\text { кількість матеріалу на } \\
\text { репродуктивному } \\
\text { рівні, виявляти } \\
\text { розуміння основних } \\
\text { положень; } \\
\text { - достатні уміння } \\
\text { аналізувати } \\
\text { навчальний матеріал } \\
\text { за певних обставин; }\end{array}$ & $\begin{array}{l}\text { - фрагментарне } \\
\text { володіння навчальним } \\
\text { матеріалом; } \\
\text { - елементарне } \\
\text { розпізнавання та } \\
\text { відтворення окремих } \\
\text { фрагментів, фактів, } \\
\text { елементів, об'єктів } \\
\text { навчального матеріалу; }\end{array}$ \\
\hline
\end{tabular}

بs 
Продовження табл. 2

\begin{tabular}{|l|}
\hline \multicolumn{1}{|c|}{1} \\
\hline - майстерні уміння \\
використовувати \\
набуті знання для \\
прийняття рішень у \\
нестандартних \\
ситуццял; \\
- грунтовні знання \\
про закони розвитку \\
сфери \\
обслуговування, \\
взаємини з клієнтами, \\
міжнародні стандарти \\
якості та традиції \\
гостинності; \\
$-\quad$ майстерні навички \\
спілуватися \\
державною та \\
іноземними мовами \\
\hline
\end{tabular}

- досконалі уміння вільно розв' язувати задачі у стандартних ситуаціях майбутньої професійної діяльності; - досконалі знання про закони розвитку сфери обслуговування, взаємини 3 клієнтами, міжнародні стандарти якості та традиціі гостинності;

- осконалі навички спілкуватися

державною та іноземними мовами

іноземними мовами

\begin{tabular}{|c|c|c|c|}
\hline \multicolumn{4}{|c|}{ Технологічно-діяльнісний критерій } \\
\hline високий (творчий) & $\begin{array}{c}\text { достатній } \\
\text { (конструктивно- } \\
\text { варіативний) } \\
\end{array}$ & $\begin{array}{c}\text { середній } \\
\text { (репродуктивний) }\end{array}$ & $\begin{array}{c}\text { низький } \\
\text { (рецептивно- } \\
\text { продуктивний) }\end{array}$ \\
\hline $\begin{array}{l}\text { - } \text { грунтовні знання } \\
\text { про предметну } \\
\text { область і специфіку } \\
\text { фахової діяльності, } \\
\text { організацію сервісно- } \\
\text { виробничого процесу; } \\
\text { - розвинена здат- } \\
\text { ність до формування } \\
\text { та реалізацї результа- } \\
\text { тивних зовнішніх та } \\
\text { внутрішніх контактів, } \\
\text { навичок взаємодії; } \\
\text { - розвинена здат- } \\
\text { ність до розроблення } \\
\text { нових послуг (продук- } \\
\text { ції) за використання } \\
\text { інноваційних техно- } \\
\text { логій відповідно до } \\
\text { сегмента споживачів; } \\
\text { - майстерні навички } \\
\text { створення концепцій } \\
\text { розвитку підпри- } \\
\text { ємств, формулювання } \\
\text { бізнес-ідеї розвитку } \\
\text { суб'єктів готельно- } \\
\text { ресторанного бізнесу; } \\
\text { - майстерні навички } \\
\text { планування, } \\
\text { управління і } \\
\text { контролю діяльності } \\
\text { суб'єктів готельно- } \\
\text { ресторанного бізнесу }\end{array}$ & $\begin{array}{l}\text { - д достатні знання про } \\
\text { предметну область і } \\
\text { специфіку фахової } \\
\text { діяльності, організацію } \\
\text { сервісно-виробничого } \\
\text { процесу; } \\
\text { - виражена здатність } \\
\text { до формування та } \\
\text { реалізації } \\
\text { результативних } \\
\text { зовнішніх та внутрішніх } \\
\text { контактів, навичок } \\
\text { взаємодії; } \\
\text { - виражена здатність } \\
\text { до розроблення нових } \\
\text { послуг (продукціі) за } \\
\text { використання } \\
\text { інноваційних } \\
\text { технологій відповідно } \\
\text { до сегмента споживачів; } \\
\text { - досконалі навички } \\
\text { створення концепцій } \\
\text { розвитку підприємств, } \\
\text { формулювання бізнес- } \\
\text { ідеї розвитку суб'єктів } \\
\text { готельно-ресторанного } \\
\text { бізнесу; } \\
\text { - досконалі навички } \\
\text { планування, управління } \\
\text { і контролю діяльності } \\
\text { суб'єктів готельно- } \\
\text { ресторанного бізнесу }\end{array}$ & $\begin{array}{l}\text { - } \text { часткові знання } \\
\text { про предметну об- } \\
\text { ласть і специфіку фа- } \\
\text { хової діяльності, орга- } \\
\text { нізацію сервісно-виро- } \\
\text { бничого процесу; } \\
\text { - } \text { наявна здатність до } \\
\text { формування та реалі- } \\
\text { зації результативних } \\
\text { зовнішніх та внутріш- } \\
\text { ніх контактів, навичок } \\
\text { взаємодії за певних } \\
\text { обставин; } \\
\text { - наявна здатність до } \\
\text { розроблення нових } \\
\text { послуг (продукціі) за } \\
\text { використання іннова- } \\
\text { ційних технологій від- } \\
\text { повідно до сегмента } \\
\text { споживачів за певних } \\
\text { обставин; } \\
\text { - достатні навички } \\
\text { створення концепцій } \\
\text { розвитку підпри- } \\
\text { ємств, формулювання } \\
\text { бізнес-ідеї розвитку } \\
\text { суб'єктів готельно- } \\
\text { ресторанного бізнесу } \\
\text { за певних обставин; } \\
\text { - достатні навички } \\
\text { планування, управлін- } \\
\text { ня і контролю діяль- } \\
\text { ності суб'єктів готель- } \\
\text { но-ресторанного } \\
\text { бізнесу }\end{array}$ & $\begin{array}{l}\text { - фрагментарні } \\
\text { знання про предметну } \\
\text { область і специфіку } \\
\text { фахової діяльності, } \\
\text { організацію сервісно- } \\
\text { виробничого процесу; } \\
\text { - відсутність або } \\
\text { низький прояв здат- } \\
\text { ності до формування та } \\
\text { реалізації зовнішніх та } \\
\text { внутрішніх контактів, } \\
\text { навичок взаємодії; } \\
\text { - відсутність або } \\
\text { низький прояв } \\
\text { здатності до } \\
\text { розроблення нових } \\
\text { послуг (продукції) та } \\
\text { використання } \\
\text { інноваційних } \\
\text { технологій; } \\
\text { - відсутність або } \\
\text { низький прояв навичок } \\
\text { створення концепцій } \\
\text { розвитку підприємств, } \\
\text { формулювання бізнес- } \\
\text { ідеї розвитку суб'єктів } \\
\text { готельно-ресторанного } \\
\text { бізнесу; } \\
\text { - відсутність або } \\
\text { низький прояв навичок } \\
\text { планування, } \\
\text { управління і контролю } \\
\text { діяльності суб'єктів } \\
\text { готельно-ресторанного } \\
\text { бізнесу }\end{array}$ \\
\hline
\end{tabular}


Продовження табл. 2

\begin{tabular}{|c|c|c|c|}
\hline 1 & 2 & 3 & 4 \\
\hline \multicolumn{4}{|c|}{ Здоров'язбережувальни } \\
\hline високий (творчий) & $\begin{array}{c}\text { достатній } \\
\text { (конструктивно- } \\
\text { варіативний) }\end{array}$ & $\begin{array}{c}\text { середній } \\
\text { (репродуктивну }\end{array}$ & \\
\hline 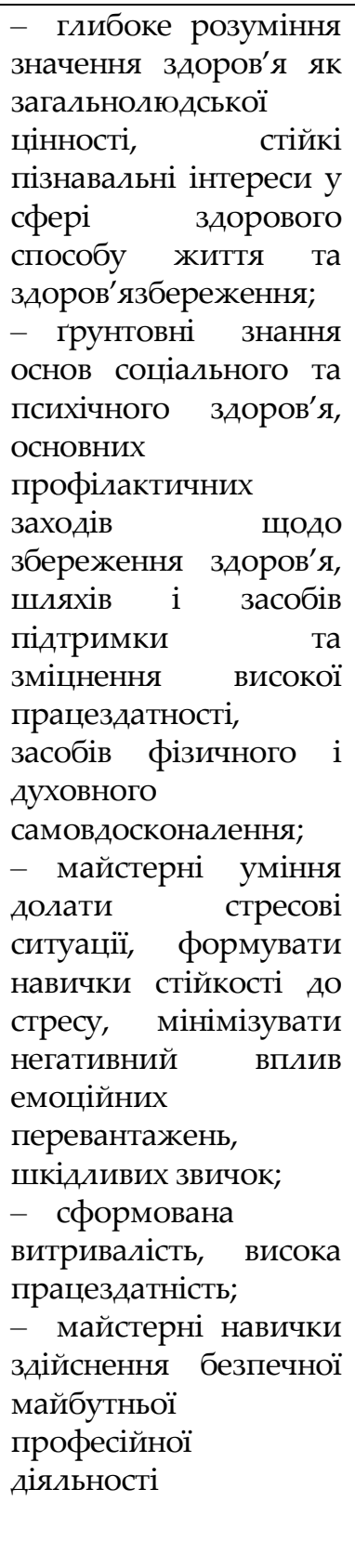 & 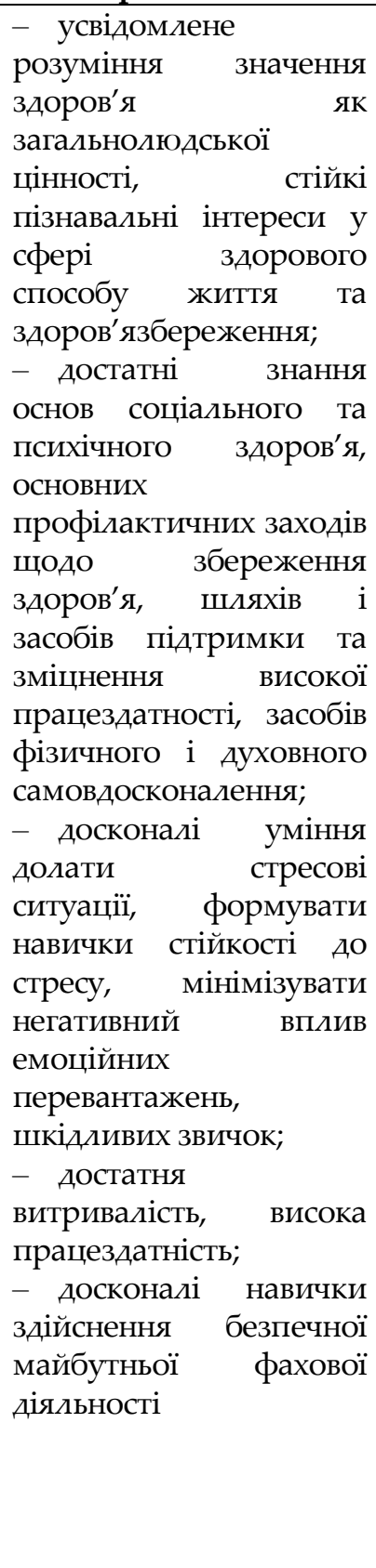 & $\begin{array}{l}\text { - достатнє } \\
\text { розуміння значення } \\
\text { здоров'я як } \\
\text { загальнолюдської } \\
\text { цінності, наявні } \\
\text { пізнавальні інтереси у } \\
\text { сфері здорового } \\
\text { способу життя та } \\
\text { здоров'язбереження; } \\
\text { - достатні знання } \\
\text { основ соціального та } \\
\text { психічного здоров'я, } \\
\text { основних } \\
\text { профілактичних } \\
\text { заходів, шляхів і } \\
\text { засобів підтримки та } \\
\text { зміцнення } \\
\text { працездатності, } \\
\text { засобів фізичного і } \\
\text { духовного } \\
\text { самовдосконалення за } \\
\text { певних обставин; } \\
- \text { достатні уміння } \\
\text { долати стресові } \\
\text { ситуації, формувати } \\
\text { навички стійкості до } \\
\text { стресу, мінімізувати } \\
\text { негативний вплив } \\
\text { емоційних } \\
\text { перевантажень, } \\
\text { шкідливих звичок за } \\
\text { певних обставин; } \\
- \text { достатня } \\
\text { витривалість, } \\
\text { працездатність за } \\
\text { певних обставин; } \\
- \text { достатні навички } \\
\text { здійснення безпечної } \\
\text { майбутньої фахової } \\
\text { діяльності за певних } \\
\text { обставин }\end{array}$ & $\begin{array}{l}\text { - фрагментарне } \\
\text { розуміння значення } \\
\text { здоров'я як } \\
\text { загальнолюдської } \\
\text { цінності, відсутність } \\
\text { або низький прояв } \\
\text { пізнавальних інтересів } \\
\text { у сфері здорового } \\
\text { способу життя та } \\
\text { здоров'язбереження; } \\
\text { - відсутність або } \\
\text { низький рівень знань } \\
\text { основ соціального та } \\
\text { психічного здоров'я, } \\
\text { основних } \\
\text { профілактичних } \\
\text { заходів, шляхів і засобів } \\
\text { підтримки та } \\
\text { зміцнення } \\
\text { працездатності, } \\
\text { фізичного і духовного } \\
\text { самовдосконалення; } \\
- \text { відсутність або } \\
\text { низький прояв умінь } \\
\text { долати стресові } \\
\text { ситуації, мінімізувати } \\
\text { негативний вплив } \\
\text { емоційних } \\
\text { перевантажень, } \\
\text { шкідливих звичок; } \\
- \text { відсутність або } \\
\text { низький прояв } \\
\text { витривалості, } \\
\text { працездатності; } \\
- \text { відсутність або } \\
\text { низький прояв навичок } \\
\text { здійснення безпечної } \\
\text { майбутньої фахової } \\
\text { діяльності }\end{array}$ \\
\hline
\end{tabular}

Висновки. Отже, здійснений аналіз дав змогу відповідно до визначених критеріїв готовності спеціалістів у сфері обслуговування диференціювати рівні сформованості готовності майбутніх фахівців готельно-ресторанної справи до професійної діяльності: високий (творчий), достатній (конструктивно-варіативний), середній (репродуктивний), низький (рецептивно-продуктивний).

Проведене дослідження не вичерпуе всіх аспектів означеної проблеми. Напрямом подальшого спрямування наукових пошуків стане дослідження формування індивідуального стилю майбутніх фахівців готельно-ресторанної справи під час професійної підготовки в закладах вищої освіти.

us 127 


\section{Список використаних джерел:}

1. Академічний тлумачний словник (1970-1980). URL: http://sum.in.ua/s/funkcija

2. Безкоровайна Л. В. Теоретичні і методичні засади професійної підготовки майбутніх фахівців з туризмознавства у вищих навчальних закладах: дис. ... д-ра. пед. наук: 13.00.04. Запоріжжя, 2018. 698 с.

3. Безрученков Ю. В. Формування професійної культури майбутніх фахівців сфери ресторанного господарства у вищому навчальному закладі: автореф. дис. ... канд. пед. наук: 13.00.04. Ауганськ, 2014. 20 с.

4. Бурак В. Г. Диверсифікація функцій професійної підготовки майбутніх фахівців готельноресторанної справи в закладах вищої освіти. Вісник Національного університету «Чернігівський колегіум» імені Т.Г. Шевченка. Серія: Педагогічні науки. 2021. Випуск 13 (169). С. 59-66.

5. Бурак В.Г. Професійна підготовка майбутніх фахівців готельно-ресторанної справи: дефінітивний аналіз. Педагогічний альманах. 2020. № 46. С. 124-131.

6. Віндюк А. В. Професійна підготовка майбутніх фахівців з готельно-курортної справи в умовах ступеневої освіти: теорія та методика: монографія. Запоріжжя: КПУ, 2011. 340 с.

7. Гарага А. В. Модель підготовки майбутніх фахівців сфери обслуговування. Економічний вісник університету. 2020. Вип. № 44. С. 50-56.

8. Короткова А. І. Критерії, показники та рівні сформованості професійної компетентності майбутніх фахівців сфери послуг в умовах освітньо-виробничого кластера. Colloquium-journal. 2020. № 31 (83). С. 51-53.

9. Лоїк Г. Б. Формування професійної компетентності майбутніх менеджерів туризму засобами інформаційно-комунікаційних технологій: дис....канд. пед. наук: 13.00.04. Тернопіль, 2014. $278 \mathrm{c.}$

10. Пюта Д. Структура, критерії та рівні готовності майбутніх фахівців із туризмознавства до професійної діяльності у сфері соціального туризму. Актуальні питання гуманітарних наук. 2020. Вип. 31. Т. 3. С. 310-315.

11. Піцул К. С. Модель формування готовності до професійної діяльності майбутніх фахівців зготельної і ресторанної справи в результаті професійної підготовки. Вісник Дніпропетровського університету імені Альфреда Нобеля. Серія: Педагогіка і психологія. 2016. № 1. C. 310-317.

12. Потапкіна $А$. Готовність фахівців готельно-ресторанної справи до інноваційної професійної діяльності: рівнева характеристика. Освітній простір України. 2018. № 14. С. 108-114.

13. Тимейчук А. М. Підготовка майбутніх магістрів з туризмознавства до проектної професійної діяльності: дис....канд. пед. наук: 13.00.04. Вінниця, 2018. 263 с.

14. Тлумачний словник української мови: близько 7000 слів / за ред. Д. Г. Гринчишина. Київ: Освіта, 1999. 302 с.

\section{References:}

1. Akademichnyi tlumachnyi slovnyk [Academic explanatory dictionary]. (1970-1980). Retrieved from http://sum.in.ua/s/funkcija [in Ukrainian].

2. Bezkorovaina, L. V. (2018). Teoretychni i metodychni zasady profesiinoi pidhotovky maibutnikh fakhivtsiv $z$ turyzmoznavstva u vyshchykh navchalnykh zakladakh [Theoretical and methodological principles of professional training of future specialists in tourism in higher educational establishments]. (Doctor's thesis). Zaporizhzhia [in Ukrainian].

3. Bezruchenkov, Yu. V. (2014). Formuvannia profesiinoi kultury maibutnikh fakhivtsiv sfery restorannoho hospodarstva $u$ vyshchomu navchalnomu zakladi [Formation of professional culture of future specialists in the field of restaurant business in higher educational establishments]. (Extended abstract of Candidate's thesis). Luhansk [in Ukrainian].

4. Burak, V. H. (2021). Dyversyfikatsiia funktsii profesiinoi pidhotovky maibutnikh fakhivtsiv hotelno-restorannoi spravy $\mathrm{v}$ zakladakh vyshchoi osvity [Diversification of professional training functions of future specialists in hotel and restaurant business in higher education institutions]. Visnyk Natsionalnoho universytetu «Chernihivskyi kolehium» imeni T. H. Shevchenka. Seriia: Pedahohichni nauky, 13 (169), 59-66 [in Ukrainian].

5. Burak, V. H. (2020). Profesiina pidhotovka maibutnikh fakhivtsiv hotelno-restorannoi spravy: definityvnyi analiz [Professional training of future specialists in hotel and restaurant business: definitive analysis]. Pedahohichnyi almanakh, 46,124-131 [in Ukrainian]. 
6. Vindiuk, A. V. (2011). Profesiina pidhotovka maibutnikh fakhivtsiv z hotelno-kurortnoi spravy v umovakh stupenevoi osvity: teoriia ta metodyka [Professional training of future specialists in hotel and resort business in the conditions of higher education: theory and methods]. Zaporizhzhia: KPU [in Ukrainian].

7. Haraha, A. V. (2020). Model pidhotovky maibutnikh fakhivtsiv sfery obsluhovuvannia [Model of training future professionals in the field of service]. Ekonomichnyi visnyk universytetu, 44, 50-56 [in Ukrainian].

8. Korotkova, L. I. (2020). Kryterii, pokaznyky ta rivni sformovanosti profesiinoi kompetentnosti maibutnikh fakhivtsiv sfery posluh $\mathrm{v}$ umovakh osvitno-vyrobnychoho klastera [Criteria, indicators and levels of future specialists' professional competence formation in service sector in the conditions of educational and production cluster]. Colloquium-journal, 31 (83), 51-53 [in Ukrainian].

9. Loik, H. B. (2014). Formuvannia profesiinoi kompetentnosti maibutnikh menedzheriv turyzmu zasobamy informatsiino-komunikatsiinykh tekhnolohii [Formation of professional competence of future tourism managers by means of information and communication technologies]. (Candidate's thesis). Ternopil [in Ukrainian].

10. Liuta, D. (2020). Struktura, kryterii ta rivni hotovnosti maibutnikh fakhivtsiv iz turyzmoznavstva do profesiinoi diialnosti u sferi sotsialnoho turyzmu [Structure, criteria and preparedness levels of future specialists in tourism for professional activity in the field of social tourism]. Aktualni pytannia humanitarnykh nauk, 31 (3), 310-315 [in Ukrainian].

11. Pitsul, K. S. (2016). Model formuvannia hotovnosti do profesiinoi diialnosti maibutnikh fakhivtsiv $\mathrm{z}$ hotelnoi i restorannoi spravy $\mathrm{v}$ rezultati profesiinoi pidhotovky [Model of formation of readiness for professional activity of future specialists in hotel and restaurant business as a result of professional training]. Visnyk Dnipropetrovskoho universytetu imeni Alfreda Nobelia. Seriia: Pedahohika i psykholohiia, 1, 310-317 [in Ukrainian].

12. Potapkina, L. (2018). Hotovnist fakhivtsiv hotelno-restorannoi spravy do innovatsiinoi profesiinoi diialnosti: rivneva kharakterystyka [Preparedness of hotel and restaurant specialists for innovative professional activity: level characteristics]. Osvitnii prostir Ukrainy, 14, 108-114 [in Ukrainian].

13. Tymeichuk, A. M. (2018). Pidhotovka maibutnikh mahistriv z turyzmoznavstva do proektnoi profesiinoi diialnosti [Training of future masters in tourism for project professional activity]. (Candidate's thesis). Vinnytsia [in Ukrainian].

14. Hrynchyshyna, D. H. (Ed.). (1999). Tlumachnyi slovnyk ukrainskoi movy [Defining dictionary of Ukrainian language]. Kyiv: Osvita [in Ukrainian].

Burak V. G., orcid.org/0000-0001-5097-6536

\section{LEVELS OF READYNESS OF FUTURE SPECIALISTS IN HOTEL AND RESTAURANT BUSINESS FOR PROFESSIONAL ACTIVITY}

The article analyzes the levels of readiness of future specialists in hotel and restaurant usiness for professional activities. The criteria of readiness of future specialists in hotel and restaurant business for professional activity are determined: value-personal, epistemological-systemic, technological-activity, health-preserving. In the context of the research, the term "level" is formulated as a degree of education, culture and preparedness for professional activity of future specialists in hotel and restaurant business. The following levels of readiness of the specialists are highlighted: high (creative), sufficient (constructive-variable), average (reproductive), low (receptive-productive). A high level is innate to students with a deep need for constant identification of special creative abilities, volitional selfregulation, independent getting of knowledge, personal self-improvement; thorough knowledge of the subject area and the specifics of professional activity, organization of service and production process and use of acquired knowledge for decision-making in non-standard situations, etc. Sufficient level is characteristic of students with significantly expressed voluntary self-regulation and ability to work in the field of "person - person"; free possession of the studied amount of material, ability to apply it in practice; sufficient knowledge of the subject area and the specifics of professional activity, organization of service and production process, etc. The average level is observed in students who are characterized by unstable voluntary self-regulation and ability to work in the field of "person - person"; lack of stable goals for personal growth, tendency to change one's beliefs and principles, etc. Low level is

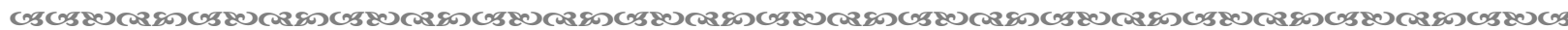


typical for students with lack or low manifestation of volitional self-regulation and ability to work in the field of "person - person"; fragmentary mastery of educational material; fragmentary knowledge about the subject area and the specifics of professional activity, organization of service and production process, etc.

Key words: future specialists, hotel and restaurant industry, preparedness, criterias, levels.

Дата надходження статmі: 12.05.2021 p.

Рецензент: доктор педагогічних наук, доцент Бордюг Н. С.

\author{
УДК 378.147 \\ DOI https://doi.org/10.37915/pa.vi49.266
}

Гуменюк I. М., orcid.org/0000-0002-0790-6732

\title{
ДІНГВІСТИЧНИЙ І ЕКСТРАЯІНГВІСТИЧНИЙ ПІДХОДИ В МЕТОДИЦІ НАВЧАННЯ УКРАЇНСЬКОЇ МОВИ ЗА ПРОФЕСІЙНИМ СПРЯМУВАННЯМ
}

Стаття присвячена вивченню потенціалу лінгвістичного та екстрахінгвістичного підходів до навчання дисцииліни «Українська мова за професійним спрямуванням» у педагогічних закладах вищої освіти. Завданням дослідження є висвітлення основних иляхів усунення орфоепічних, акцентуаційних, лексичних, синтаксичних і пунктуаційних недоліків професійного мовлення майбутніх учителів початкових класів у межах навчального курсу. Наоснові аналізу інформаційного простору проблеми встановлено, що перспективи застосування хінгвістичного підходу в контексті украйнської мови за професійним спрямуванням представлені незначною кількістю публікацій. Аексичний аспект професійного мовлення спрямований на формування термінологічної компетентності студентів і частково - на розкриття методики лексичної сполучуваності у фаховій мові та усунення лексичних помилок. Наголошено на актуальності проблем надмірного вживання пасивних дієслівних форм і неправильної побудови прийменникових конструкцій у писемному діловому мовленні, а також можливостях їх вирішення у межах курсу. Окреслено основні аспекти вдосконалення синтаксичного й пунктуаційного оформлення професійного мовлення студентів та невирішені питання у цъвому контексті.

Аінгвістичний підхід до навчання української мови за професійним спрямуванням охоплюе реалізаціюо прагмалінгвістичних категорій у професійній комунікацій, зокрема мікропрагматичних одиниць (рівень мовияя), макропрагматичних (рівень рецииієнта), мегапрагматичних (соизіальний рівень). Акцентовано на відсутності досліджень методики навчання особливостям застосування екстралінгвістичних засобів у професійному спілкуванні. Підтверджено необхідність інтегрованого застосування лінгвістичного підходу до навчання української мови за професійним спрямуванням поряд з іншими концеептуальними підходами до мовної освіти.

Ключові слова: професійне мовлення, лінгвістичний підхід, екстралінгвістичний підхід, лексична норма, синтаксична норма, прагмахінгвістичні категорії, комунікація, лінгвістична компетентність.

Постановка проблеми. Професійне мовлення знаходить своє вираження в усній та писемній формах української літературної мови. Дотримання орфоепічних, акцентуаційних, лексичних, фразеологічних та інших норм в усній професійній комунікації є показником інтелектуального та культурного рівня мовця, як і дотримання орфографічних, пунктуаційних, стилістичних норм у писемній формі. Тому лінгвістичний підхід до навчання української мови за професійним спрямуванням

*C) Гуменюк I. М.

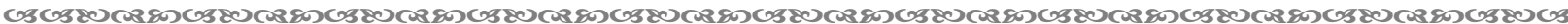
130 